\title{
Isolation and characterization of highly pathogenic avian influenza virus subtype H5N1 from donkeys
}

\author{
Ahmed S Abdel-Moneim*1,2, Ahmad E Abdel-Ghany ${ }^{3}$ and Salama AS Shany ${ }^{4}$
}

\begin{abstract}
Background: The highly pathogenic H5N1 is a major avian pathogen that crosses species barriers and seriously affects humans as well as some mammals. It mutates in an intensified manner and is considered a potential candidate for the possible next pandemic with all the catastrophic consequences.

Methods: Nasal swabs were collected from donkeys suffered from respiratory distress. The virus was isolated from the pooled nasal swabs in specific pathogen free embryonated chicken eggs (SPF-ECE). Reverse transcriptase polymerase chain reaction (RT-PCR) and sequencing of both haemagglutingin and neuraminidase were performed. H5 seroconversion was screened using haemagglutination inhibition $(\mathrm{HI})$ assay on 105 donkey serum samples.

Results: We demonstrated that H5N1 jumped from poultry to another mammalian host; donkeys. Phylogenetic analysis showed that the virus clustered within the lineage of H5N1 from Egypt, closely related to 2009 isolates. It harboured few genetic changes compared to the closely related viruses from avian and humans. The neuraminidase lacks oseltamivir resistant mutations. Interestingly, $\mathrm{HI}$ screening for antibodies to $\mathrm{H} 5$ haemagglutinins in donkeys revealed high exposure rate.
\end{abstract}

Conclusions: These findings extend the host range of the H5N1 influenza virus, possess implications for influenza virus epidemiology and highlight the need for the systematic surveillance of $\mathrm{H} 5 \mathrm{~N} 1$ in animals in the vicinity of backyard poultry units especially in endemic areas.

\section{Background}

Influenza A viruses belong to the family Orthomyxoviridae and have been isolated from a variety of different species. Further subtyping of influenza A viruses is based on antigenic differences between the two surface glycoproteins haemagglutinin (H1-H16) and neuraminidase (N1N9) of the influenza A viruses [1,2]. The HA mediates the attachment of the virus to sialic-acid-containing receptors on the host cell surface, as well as the fusion of the virus envelope with the cellular membrane [3,4]. The specificity of the HA towards these molecules differs. Avian and equine influenza viruses preferentially bind the sialic acid $\alpha$-2,3-galactose (SA $\alpha 2,3 \mathrm{Gal})$ linkage, while human influenza viruses preferentially bind the SA 2 ,6Gal linkage [5-7]. The highly pathogenic avian influenza virus H5N1 (HPAIV- H5N1) represents an

* Correspondence: asa@bsu.edu.eg

1 Department of Virology, Faculty of Veterinary Medicine, Beni-Suef University, Beni-Suef 62511, Egypt

Full list of author information is available at the end of the article important poultry pathogen and a major havoc to the poultry industry. Furthermore, HPAIV H5N1 infections in poultry constitute a threat to mammals including humans. Apart from humans, the natural infections of H5N1 influenza A have been reported in several mammalian species including domestic cats [8], tigers and leopards [9], dogs [10], pigs [11] and stone marten [12]. Experimentally, H5N1 has also been able to infect mice [13], ferrets [14], monkeys [15] and cattle [16]. Infections in either experimental or naturally infected hosts have been fatal except for pigs and cattle where mild to subclinical infections have been detected $[11,16]$. No naturally occurring cases of H5N1 HPAI have been reported in horses or other members of the Perissodactyla order nor have any experimental studies been published [17]. An equine influenza virus; H3N8 with avian gene pool has been isolated emphasizing that equines may be susceptible to avian influenza viruses of the H3N8 subtype[18] and possibly others. The family Equidae and in particular donkeys may be of great importance in certain endemic 
countries like Egypt where they are commonly housed together with poultry. Long term endemic influenza virus infections in poultry increase exposure risks to surrounding humans and other mammals and in turn, create opportunities for the emergence of human-adapted strains with pandemic potential [19,20]. Since 2006, H5N1 influenza A virus has been endemic in Egypt producing great economic losses and most importantly hitting humans hard with high case fatality rate; 34/109 (WHO; http://www.who.int/csr/disease/avian_influenza/ country/cases table 2010 04 09/en/index.html).

Here we report the isolation of HPAI H5N1 from donkeys living in contact with diseased birds and demonstrate the presence of $\mathrm{H} 5$ seropositive ones in the neighbouring areas.

\section{Methods}

\section{Virus isolation}

Nasal swabs were collected from three infected animals from Aborady village, El-Wasta locality, Beni-Suef Gover- norate. Each swab was placed in a tube containing $0.5 \mathrm{ml}$ sterile normal saline containing gentamicin sulfate solution $(50 \mathrm{mg} / \mathrm{ml})$. The swab tip was cut off in the saline and the tubes were immediately transported to the lab for testing in an ice box to be processed using a routine method. Infected materials were pooled, centrifuged at $500 \mathrm{xg}$ for $10 \mathrm{~min}$. and then inoculated into the allantoic cavity of five, 10-day-SPF-ECE $(100 \mu \mathrm{l} / \mathrm{egg})$. Inoculated embryos were incubated at $37^{\circ} \mathrm{C}$ for $24-48 \mathrm{~h}$.

\section{Haemagglutination inhibition}

One hundred and five serum samples were collected from apparently healthy donkeys from different localities in the Beni-Suef Governorate, 4-6 months after the procedure of virus isolation. Sera were heat inactivated for $30 \mathrm{~min}$ at $56^{\circ} \mathrm{C}$ and 2 -fold serial dilutions were performed in $25-\mu \mathrm{L}$ volume in 96-well HI plates. Equal volumes of 4HA of H5 influenza virus antigen (A/chicken/Egypt/F6/ 2007(H5N1)) were added to diluted serum samples then $1 \%$ suspension of human erythrocytes were dispensed to

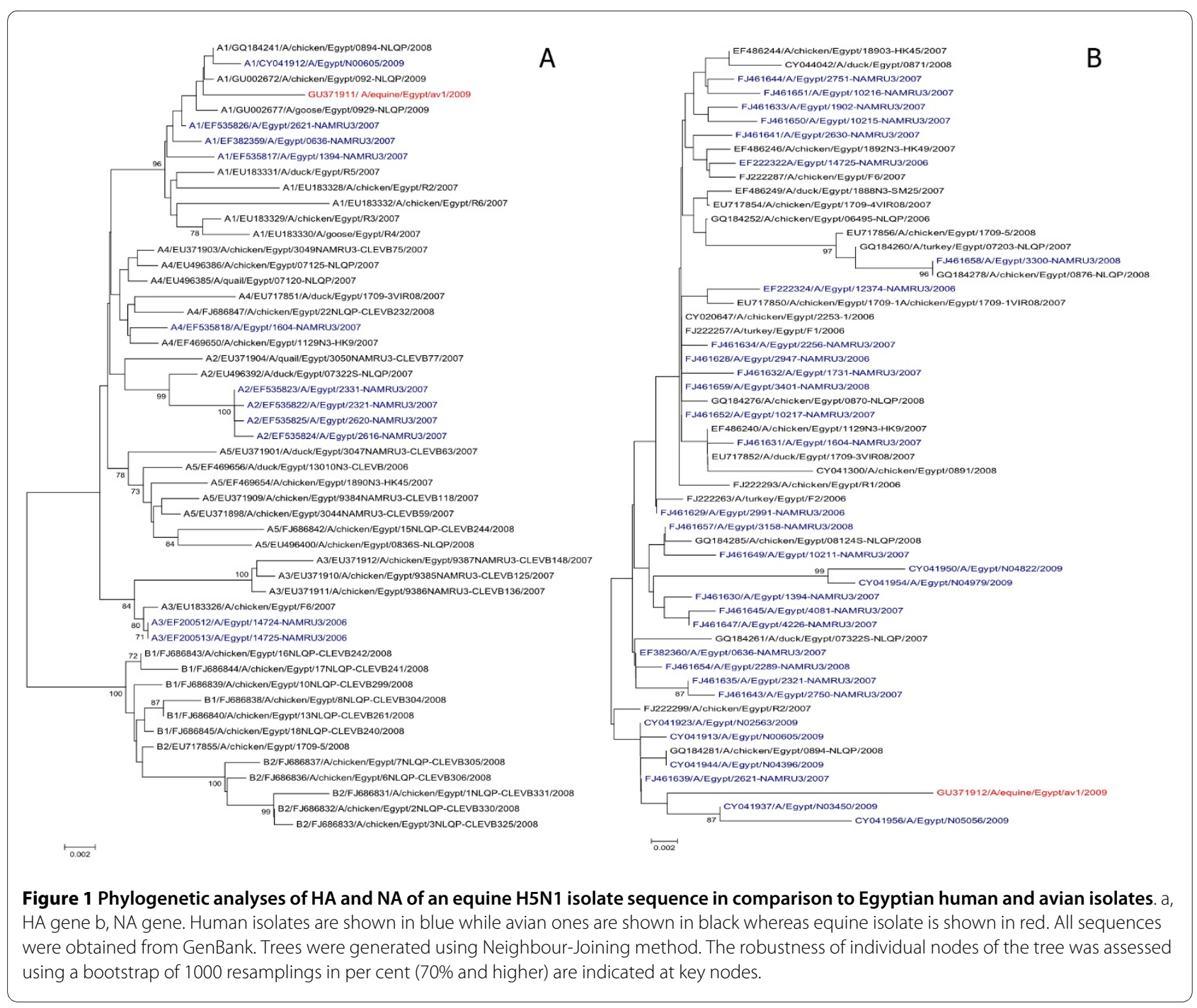


each well [21]. HI titers $\geq 3 \log _{2}$ were considered positive. Samples assayed in duplicates and each assay was validated by comparison with positive and negative chicken and equine control sera as well as back titration of the used virus dilutions.

\section{Viral RNA extraction and RT PCR}

Viral RNA was extracted from virus containing chorioallantoic membranes (CAM) homogenate by using a SV Total RNA Isolation System (Promega Corporation, Madison, Wis.). The sample was processed alone in a sterile clean room to avoid the possibility of any cross contamination. One-step RT-PCR amplification for full length of both NA and HA genes were performed using Verso $^{\text {Tw }} 1$ step RT PCR (Thermo Fisher Scientific Inc.). A single set of primers was used for NA (For:ATGAATCCAAATCAGAAG,

Rev:TGTCAATGGTGAATG-

GCAAC) but for HA, four sets of primers flanking overlapping regions of the full length gene were used (Primer sequences for HA were ordered according to that provided by; Laboratory for Molecular and Biological Characterization of AIV, FLI, Germany).

\section{Sequence analysis}

Amplicons were first subjected to $1 \%$ gel electrophoresis and specific bands were excised and purified using EzWayTM gel extraction kit (Komabiotech, Korea). Each purified amplicon was sequenced in both forward and reverse directions (Macrogen Inc., Korea).

\section{Phylogenetic Analysis}

BLAST analyses were initially performed to establish HA and NA sequence identities to GenBank accessions [22]. Comparative analyses were performed using the CLUSTAL W Multiple Sequence Alignment Program, Mega 3.1. AIV representative sequences used for the alignments were obtained from the GenBank and EMBL database. The phylogenetic trees were constructed by using the neighbour-joining method with Kimura twoparameter distances by using MEGA version 3.1 [23]. The reliability of internal branches was assessed by 1000 bootstrap replications and p-distance substitution model.

\section{Results and discussion}

In this study, we isolated H5N1 form donkeys clinically affected with moderate respiratory distress including


Figure 2 Deduced amino acid sequences of the HA protein of equine H5N1 isolate in comparison to closely related Egyptian HPAIV H5N1 isolates. Dots denote identical amino acids, which are given in one-letter code. Consensus sequences for N-glycosylation (NXS or NXT, except where $\mathrm{X}=\mathrm{P}$ ) are underlined. Boxed segments indicate the signal peptide and the polybasic proteolytic cleavage motif, respectively. Shaded letters denote potential sites responsible for receptor binding sites ( $\mathrm{H} 3$ influenza numbering) 

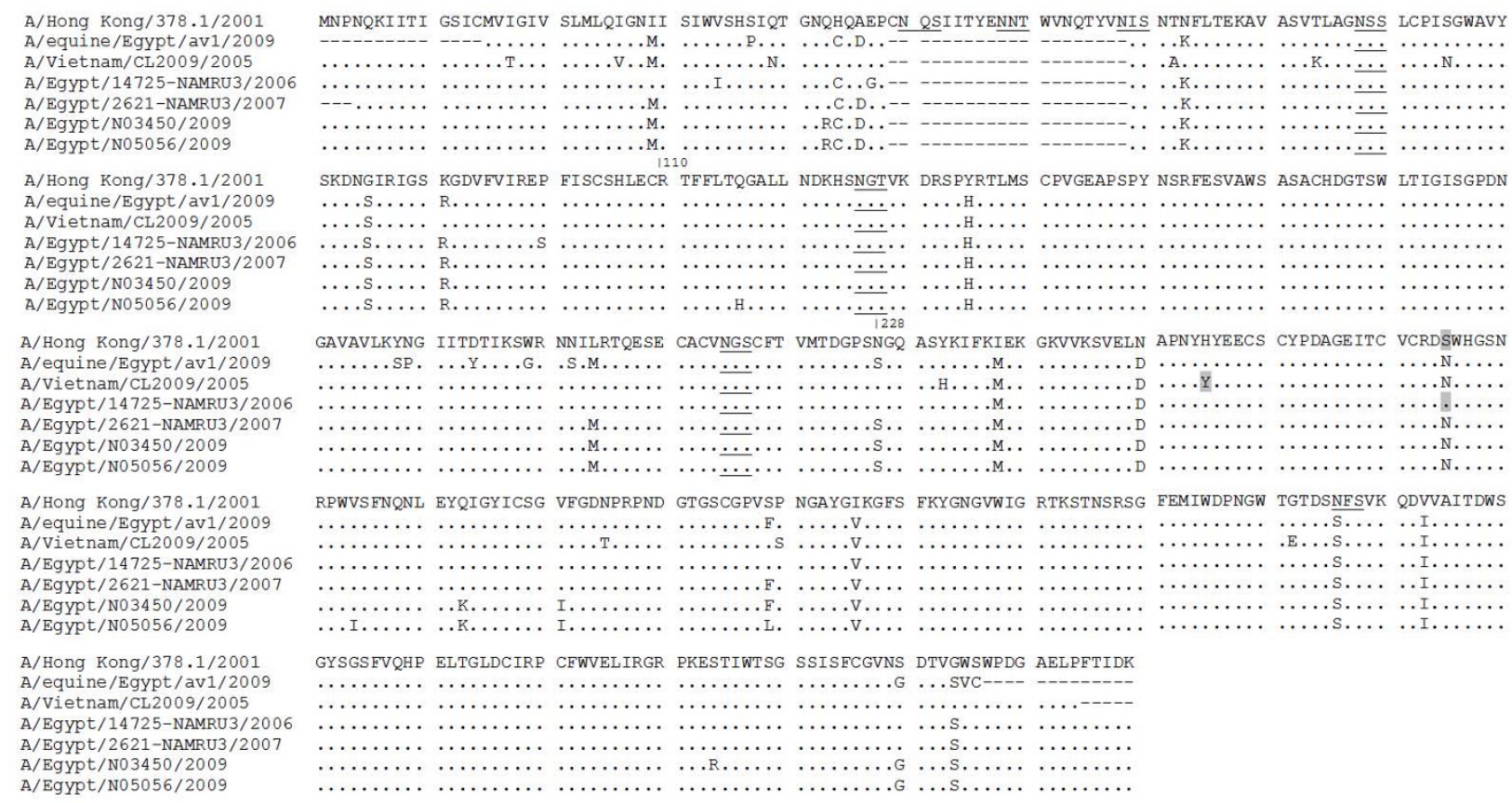

Figure 3 Deduced amino acid sequences of NA protein of equine H5N1 isolate in comparison to two recent closely related and other distant isolates that showed resistant to oseltamivir. Dots indicate residues identical amino acids. Underlined letters are $\mathrm{N}$-glycosylation sites, shaded letters showed site of H274Y and N294S substitutions (H275Y and N295S in N1 influenza numbering).

cough, fever and serous nasal discharge. The course of the disease was short $(72 \mathrm{~h})$ and responsive well after two shots of streptomycin/penicillin antibiotic therapy and one shot of antipyretic (Diclofenac sodium) with no recorded mortalities. The inhibition induced by antibiotic to the possible secondary bacterial invasion, besides the moderate severity of the H5N1 in donkeys may be responsible for the recovery of the infected animals without further complications. The disease recoded on $24^{\text {th }}$ March 2009, 1 wk after an outbreak of H5N1 infection in poultry in the village, where many donkeys suffered from the same clinical manifestations in an epidemic manner. The virus was isolated from a pool of nasal discharge from three affected animals. It produced haemagglutination only after the $3^{\text {rd }}$ egg passage. RT-PCR was performed to the full length of both NA and HA genes, where they were sequenced directly after gel purification. Sequences were deposited in GenBank under accession numbers; GU371911 and GU371912 for HA and NA respectively. The $\mathrm{HA}$ and NA genes of the investigated equine isolates revealed that they belonged to (5J), (1J) lineages respectively (According to the Influenza A Virus Genotype Tool) [24]. Phylogenetic analyses revealed that the HA of the equine isolate related to sublineages, A (A1) (Fig. 1). The equine isolate showed a typical polybasic cleavage motif with the GERRRKKR*GLF consensus sequence found in clade 2.2 viruses. It also contains amino acid D403 characteristic to sub-clade 2.2.1 (Fig. 2).
The haemagglutinin gene was found to be closely related to A/chicken/Egypt/0894-NLQP/2008, A/Egypt/N00605/ 2009 and A/chicken/Egypt/092-NLQP/2009 while the neuraminidase gene of the current strain is closely related to A/Egypt/N03450/2009 and A/Egypt/N05056/2009. However, none of these strains were isolated from localities near to Beni-Suef.

The equine isolate has amino acids Q226 and G228 (H3 influenza numbering) denoting the preferential binding

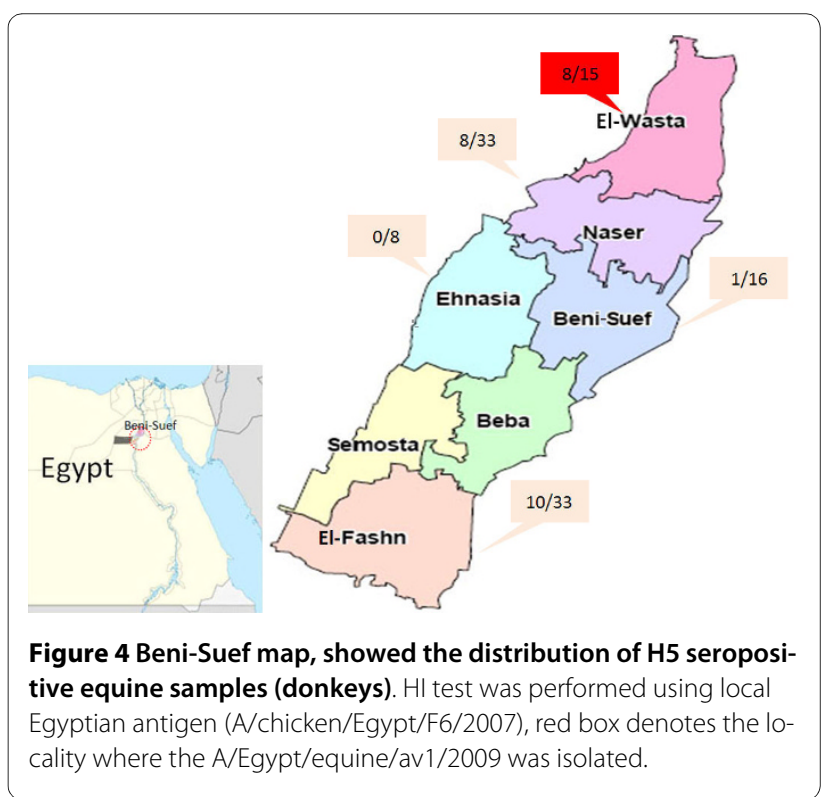


Table 1: Serological screening of H5N1 exposure in donkeys from different localities of Beni-Suef Governorate using haemagglutination inhibition assay

\begin{tabular}{cccccc}
\hline Locality & & Samples & & $\begin{array}{c}\text { HI range } \\
\text { (Log2) }\end{array}$ \\
& Number & Positive & Negative & Positive \% & \\
\cline { 2 - 5 } & 16 & 1 & 15 & 6.25 & 7 \\
Beni-Suef & 33 & 10 & 23 & 30.30 & $8-10$ \\
El-Fashn & 8 & 0 & 8 & 00.00 & $0-2$ \\
Ehnasia & 15 & 8 & 7 & 53.33 & $6-9$ \\
El-Wasta & 33 & 8 & 25 & 24.24 & $7-8$ \\
Naser & 105 & 27 & 78 & 25.71 & \\
Total & & & & & 7 \\
\hline
\end{tabular}

of $\alpha-2,3$ linkage, typical for the avian and equine viruses but not human ones [5,25]. This finding demonstrated that the isolates with avian specific receptor binding properties can replicate and cause infection in equines. Different amino-acids that are implicated in receptor specificity Y98, S136, W153, H183, E190, K193 L194 E216 P221 K222 G225, Q226, S227, G228 (H3 influenza numbering) were tested [26]. Interestingly 98 ( $\mathrm{Y}$ to $\mathrm{N}$ ), 193 ( $\mathrm{K}$ to $\mathrm{R}$ ), 216 ( $\mathrm{E}$ to $\mathrm{K}$ ) and 221( $\mathrm{P}$ to $\mathrm{S}$ ) which were found in the examined equine isolate have also been in many other isolates from the middle east in the flu database which raises a question as to what the impact of such substitution on HA binding to human receptors is. Recently, A138V, N186K and S227N mutations were reported to confer $\alpha$-2,6-linked sialic acid binding to $\mathrm{H} 5 \mathrm{~N} 1$ virus [27-30]. None of such substitutions were found in the equine isolate. The HA of the human or avian Egyptian isolates, contains a total of seven potential $\mathrm{N}$-glycosylation signals whereas the equine isolate contains an additional N-glycosylation (Fig. 2).

In addition, the equine isolate lacks aa S145. This deletion is also present in all other viruses grouped into 2.2 sublineage A1, which also includes sequences from human $\mathrm{H} 5 \mathrm{~N} 1$ isolates (Fig. 2). The significance of this deletion is unknown, but it should be noted that this position is close to a domain modulating receptor interaction. Interestingly, strains with this deletion appear to evolve towards a receptor usage that is similar to that of the seasonal human $\mathrm{H} 1 \mathrm{~N} 1[31]$.

Analysis of the NA gene revealed the presence of the 20-amino acid deletion (Fig. 3) as well as the presence of amino-acid $\mathrm{R}$ at position 110 which is characteristic of clade 2.2 viruses [32]. Three potential N-glycosylation sites were predicted (Fig. 3). The 228 ( $\mathrm{N}$ to S) substitution is also present and indicative to 2.2.1 virus (2009). Four NA mutations; E119G, H274Y, R292K, and N294S have been reported to confer resistance to NA inhibitors [33] but none were detected in the equine isolate.
Speculating that infected animals may mount an antibody response depending on the interval post infection, we screened H5-specific antibodies 4-6 months after the initial virus isolation. The $\mathrm{H} 5$ specific antibodies were detected in naturally affected animals. 27 out of 105 (25.71\%) of the examined animals were H5 positive with the highest percentage found in the area where the virus was isolated (Table 1, Fig. 4).

\section{Conclusion}

We did note the incidence of clinical infections of donkeys with HPAIV (H5N1) in disease endemic regions where the probability of intimate contact between poultry and donkeys is high. Furthermore, H5 seroconversion by naturally exposed donkeys was evidenced. Although the disease did not constitute a real threat to donkeys, it raises the concern of different issues including the route of transmission to donkeys, whether being from aerosol exposure of pulverized infected birds droppings or contaminated feeds and water or because of contact with infected birds. Second, the role of donkeys in spreading $\mathrm{H} 5 \mathrm{~N} 1$ virus to birds, humans and other mammals including equines needs to be assessed.

\section{Competing interests}

The authors declare that they have no competing interests.

\section{Authors' contributions}

ASA and AEA designed, performed experiments, and analyzed data. ASA generated genetic constructs and drafts the manuscript. AEA and SASS performed the $\mathrm{HI}$ analyses and helped in RT-PCR. AEA reviewed the manuscript.

\section{Author Details}

'Department of Virology, Faculty of Veterinary Medicine, Beni-Suef University, Beni-Suef 62511, Egypt, 2Division of Virology, Department of Microbiology, College of Medicine and Medical Sciences, Taif University, Al-Taif, Saudi Arabia, 3Department of Hygiene, Management \& Zoonoses, Faculty of Veterinary Medicine, Beni-Suef University, Beni-Suef 62511, Egypt and 4Department of Poultry Diseases, Faculty of Veterinary Medicine, Beni-Suef University, Beni-Suef 62511, Egypt

Received: 2 February 2010 Accepted: 14 April 2010 Published: 14 April 2010 


\section{References}

1. Murphy BR, Webster RG: Orthomyxoviruses. In Fields Virology Philadelphia: Lippincott-Raven; 1996.

2. Fouchier RAM, Munster V, Wallensten A, Bestebroer TM, Herfst S, Smith D, Rimmelzwaan GF, Olsen B, Osterhaus AD: Characterization of a novel influenza A virus hemagglutinin subtype (H16) obtained from blackheaded gulls. J Virol 2005, 79(5):2814-22.

3. Rott R, Klenk HD, Nagai Y, Tashiro M: Influenza viruses, cell enzymes, and pathogenicity. Am J Respir Crit Care Med 1995, 152:S16-S19.

4. Katz JM, Lu X, Tumpey TM, Smith CB, Shaw MW, Subbarao K: Molecular correlates of influenza A H5N1 virus pathogenesis in mice. J Virol 2000, 74:10807-10810.

5. Connor RJ, Kawaoka Y, Webster RG, Paulson JC: Receptor specificity in human, avian, and equine $\mathrm{H} 2$ and $\mathrm{H} 3$ influenza virus isolates. Virology 1994, 205:17-23.

6. Rogers GN, Paulson JC: Receptor determinants of human and animal influenza virus isolates: differences in receptor specificity of the $\mathrm{H} 3$ hemagglutinin based on species of origin. Virology 1983, 127:361-373.

7. Rogers GN, D'Souza BL: Receptor binding properties of human and animal H1 influenza virus isolates. Virology 1989, 173:317-322.

8. Kuiken T, Rimmelzwaan G, van Riel D, van Amerongen G, Baars M, Fouchier R, Osterhaus A: Avian H5N1 influenza in cats. Science 2004, 306:241.

9. Keawcharoen J, Oraveerakul K, Kuiken T, Fouchier RA, Amonsin A, Payungporn S, Noppornpanth S, Wattanodorn S, Theambooniers A Tantilertcharoen R, Pattanarangsan R, Arya N, Ratanakorn P, Osterhaus DM, Poovorawan Y: Avian influenza H5N1 in tigers and leopards. Emerg Infect Dis 2004, 10:2189-2191.

10. Songserm T, Amonsin A, Jam-on R, Sae-Heng N, Pariyothorn N, Payungporn S, Theamboonlers A, Chutinimitkul S, Thanawongnuwech R, Poovorawan Y: Fatal avian influenza A H5N1 in a dog. Emerg Infect Dis 2006, 12:1744-1747.

11. Li HY, Yu K, Yang H, Xin X, Chen J, Zhao P, Bi Y: Isolation and characterization of $\mathrm{H} 5 \mathrm{~N} 1$ and $\mathrm{H} 9 \mathrm{~N} 2$ influenza viruses from pigs in China. Chin J Prev Vet Med 2004, 26:1-6.

12. Klopfleisch R, Wolf PU, Wolf C, Harder T, Starick E, Niebuhr M, Mettenleiter TC, Teifke JP: Encephalitis in a stone marten (Martes foina) after natural infection with highly pathogenic avian influenza virus subtype H5N1. J Comp Pathol 2007, 137:155-159.

13. Gao P, Watanabe S, Ito T, Goto H, Wells K, McGregor M, Cooley AJ, Kawaoka Y: Biological heterogeneity, including systemic replication in mice, of H5N1 influenza A virus isolates from humans in Hong Kong. J Virol 1999, 73:3184-3189.

14. Zitzow LA, Rowe T, Morken T, Shieh WJ, Zaki S, Katz JMx: Pathogenesis of avian influenza $A$ (H5N1) viruses in ferrets. J Virol 2002, 76:4420-4429.

15. Kuiken T, Rimmelzwaan GF, Van Amerongen G, Osterhaus AD: Pathology of human influenza $A$ (H5N1) virus infection in cynomolgus macaques (Macaca fascicularis). Vet Pathol 2003, 40:304-310.

16. Kalthoff D, Hoffmann B, Harder T, Durban M, Beer M: Experimental infection of cattle with highly pathogenic avian influenza virus (H5N1). Emerg Infect Dis 2008, 14:1132-1134.

17. Cardona CJ, Xing Z, Sandrock CE, Davis CE: Avian influenza in birds and mammals. Comp Immunol Microbio Infec Dis 2009, 32(4):255-273.

18. Guo Y, Wang M, Kawaoka Y, Gorman O, Ito T, Saito T, Webster RG: Characterization of a new avian-like influenza $A$ virus from horses in China. Virology 1992, 188:245-255.

19. Matrosovich M, Zhou N, Kawaoka Y, Webster R: The surface glycoproteins of $\mathrm{H} 5$ influenza viruses isolated from humans, chickens, and wild aquatic birds have distinguishable properties. J Virol 1999, 73:1146-1155.

20. Webster RG, Wright SM, Castrucci MR, Bean WJ, Kawaoka Y: Influenza-a model of an emerging virus disease. Intervirology. 1993, 35(1-4):16-25

21. Beard CW: Serological procedures. In American Association of Avian Pathologists lowa: Kendall/Hunt Publishing Company; 1989

22. Altschul SF, Gish W, Miller W, Myers EW, Lipman DJ: Basic local alignment search tool. J Mol Biol 1990, 15:403-410.

23. Kumar S, Tamura K, Jakobsen IB, Nei M: Molecular evolutionary genetics analysis software. Bioinformatics 2001, 17(12):1244-1245

24. Lu G, Rowley T, Garten R, Donis RO: FluGenome: a web tool for genotyping influenza A virus. Nucleic Acids Res 2007, 35:W275-279
25. Suzuki Y, Ito T, Suzuki T, Holland RJ, Chambers TM, Kiso M, Ishida H, Kawaoka Y: Sialic acid species as a determinant of the host range of influenza a viruses. J Virol 2000, 74:11825-11831.

26. Stevens J, Blixt O, Tumpey TM, Taubenberger JK, Paulson JC, Wilson IA: Structure and receptor specificity of the hemagglutinin from an $\mathrm{H} 5 \mathrm{~N} 1$ influenza virus. Science. Science 2006, 312:404-410.

27. Shinya K, Hatta M, Yamada S, Takada A, Watanabe S, Halfmann P, Horimoto T, Neumann G, Kim JH, Lim W, Guan Y, Peiris M, Kiso M, Suzuki T, Suzuki Y, Kawaoka Y: Characterization of a human H5N1 influenza A virus isolated in 2003. J Virol 2005, 79:9926-9932.

28. Gambaryan A, Tuzikov A, Pazynina G, Bovin N, Balish A, Klimov A Evolution of the receptor binding phenotype of influenza $A(\mathrm{H} 5)$ viruses. Virology 2006, 344:432-438.

29. Yamada S, Suzuki Y, Suzuki T, Le MQ, Nidom CA, Sakai-Tagawa Y, Muramoto Y, Ito M, Kiso M, Horimoto T, Shinya K, Sawada T, Kiso M, Usui T, Murata T, Lin Y, Hay A, Haire LF, Stevens DJ, Russell RJ, Gamblin SJ, Skehel $J$ J, Kawaoka Y: Haemagglutinin mutations responsible for the binding of H5N1 influenza A viruses to human-type receptors. Nature 2006, 444:378-382.

30. Auewarakul P, Suptawiwat O, Kongchanagul A, Sangma C, Suzuki Y, Ungchusak K, Louisirirotchanakul S, Lerdsamran $\mathrm{H}$, Pooruk P, Thitithanyanont A, Pittayawonganon C, Guo CT, Hiramatsu H, Jampangern W, Chunsutthiwat S, Puthavathana P: An avian influenza H5N1 virus that binds to a human-type receptor. J Virol 2007, 81:9950-9955.

31. Veljkovic V, Veljkovic N, Muller CP, Müller S, Glisic S, Perovic V, Köhler H: Characterization of conserved properties of hemagglutinin of $\mathrm{H} 5 \mathrm{~N} 1$ and human influenza viruses: possible consequences for therapy and infection control. BMC Struct Biol 2009, 9:21.

32. Chen H, Smith GJ, Li KS, Wang J, Fan XH, Rayner JM, Vijaykrishna D, Zhang JX, Zhang LJ, Guo CT, Cheung CL, Xu KM, Duan L, Huang K, Qin K, Leung YH, Wu WL, Lu HR, Chen Y, Xia NS, Naipospos TS, Yuen KY, Hassan SS, Bahri S, Nguyen TD, Webster RG, Peiris JS, Guan Y: Establishment of multiple sublineages of $\mathrm{H} 5 \mathrm{~N} 1$ influenza virus in Asia: implications for pandemic control. Proc Natl Acad Sci USA 2006, 103:2845-2850.

33. Yen HL, Ilyushina NA, Salomon R, Hoffmann E, Webster RG, Govorkova EA: Neuraminidase inhibitor-resistant recombinant A/Vietnam/1203/04 (H5N1) influenza viruses retain their replication efficiency and pathogenicity in vitro and in vivo. J Virol 2007, 81(22):12418-12426.

doi: 10.1186/1423-0127-17-25

Cite this article as: Abdel-Moneim et al., Isolation and characterization of highly pathogenic avian influenza virus subtype H5N1 from donkeys Journal of Biomedical Science 2010, 17:25

\section{Submit your next manuscript to BioMed Central and take full advantage of:}

- Convenient online submission

- Thorough peer review

- No space constraints or color figure charges

- Immediate publication on acceptance

- Inclusion in PubMed, CAS, Scopus and Google Scholar

- Research which is freely available for redistribution 